\title{
A DETECTION SYSTEM OF EXERCISE ELECTROCARDIOGRAM
}

\author{
UM SISTEMA DE DETECÇÃO DE ELETROCARDIOGRAMA DE EXERCÍCIO
}

\section{UNSISTEMA DEDETECCIÓN DE ELECTROCARDIOGRAMA DEEJERCICIO}

Meng Zhang

(Physical Education Professional)

Yifei Zhai' 1 (D)

(Physical Education Professional)

1. Nanjing University, Nanjing,

China.

\section{Correspondence:}

Yifei Zhai

Nanjing University,Nanjing 210093,

China.zhaiyifeinju@126.com

\section{ABSTRACT}

Original Article

Artigo Original

Artículo Original

Introduction: A new exercise electrocardiogram (ECG) detection system was investigated in this study to diagnose and analyze cardiopulmonary function and related diseases in a comprehensive and timely manner and improve the accuracy of diagnosis. Besides, its reliability and clinical applicability were judged. Objective: A new type of exercise ECG detection system was constructed by adding parameters such as respiratory mechanics, carbon dioxide, and oxygen concentration monitoring based on the traditional ECG detection system. Methods: The new system constructed in this study carried out the ECG signal detection, ECG acquisition module, blood pressure and respiratory mechanics detection and conducted a standard conformance test. Results: The heart rate accuracy detected by the exercise ECG system was greatly higher than that of the doctor's manual detection $(P<0.05)$. The accuracy of the new exercise ECG detection system increased obviously in contrast to that of the manual detection result $(P<0.05)$. The key technical index input noise and input impedance test results $(24.5 \mu \mathrm{V}$ and 12.4 $\mathrm{M} \Omega$ ) of the exercise ECG detection system conformed to the standard ( $<30 \mu \mathrm{V}$ and $>2.5 \mathrm{M} \Omega$ ). The common-mode rejection and sampling rate test results $(103.5 \mathrm{~dB}$ and $515 \mathrm{~Hz})$ of key technical indicators in the exercise ECG detection system were all in line with the standards ( $\geq 89 \mathrm{~dB}$ and $\geq 500 \mathrm{~Hz}$ ). Conclusion: The complete exercise ECG detection system was constructed through the ECG acquisition module, blood pressure detection, and respiratory mechanics detection module. In addition, this system could be applied to detect ECG monitoring indicators with high accuracy and reliability, which could also be extensively adopted in clinical diagnosis. Level of evidence II; Therapeutic studies - investigation of treatment results.

Keywords: Electrocardiography; Heart function tests; Heart rate; Exercise test.

\section{RESUMO}

Introdução: Um novo sistema de detecção de eletrocardiograma de exercício (ECG) foi investigado neste estudo para diagnosticar e analisar a função cardiopulmonar e doenças relacionadas de maneira abrangente e oportuna e melhorar a precisão do diagnóstico. Além disso, sua confiabilidade e aplicabilidade clínica foram julgadas. Objetivo: Um novo tipo de sistema de deteç̧ão de ECG de esforço foi construído adicionando parâmetros como mecânica respiratória, dióxido de carbono e monitoramento da concentração de oxigênio com base no sistema de detecção de ECG tradicional. Métodos: O novo sistema construído neste estudo realizou a detecção do sinal de ECG, módulo de aquisição de ECG e detecção de pressão arterial e mecânica respiratória, e conduziu um teste de conformidade padrão. Resultados: A precisão da frequência cardíaca detectada pelo sistema de ECG de esforço foi muito maior do que a detecção manual do médico $(P<0,05)$. A precisão do novo sistema de detecção de $E C G$ de esforço aumentou obviamente em contraste com o resultado da detecção manual $(P<0,05)$. O ruído de entrada

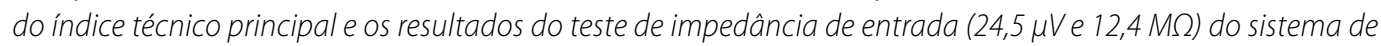
detecção de ECG de esforço estão em conformidade com o padrão ( $<30 \mu \mathrm{V}$ e $>2,5 \mathrm{M} \Omega)$. A rejeição do modo comum e os resultados do teste de taxa de amostragem (103,5 dB e $515 \mathrm{~Hz})$ dos indicadores técnicos principais no sistema de detecção de ECG de esforço estavam todos alinhados com os padrões ( $\geq 89 \mathrm{~dB}$ e $\geq 500 \mathrm{~Hz}$ ). Conclusão: O sistema completo de deteç̧ão de ECG de esforço foi construído através da combinação de módulo de aquisição de ECG, detecção de pressão arterial e módulo de detecção de mecânica respiratória. Além disso, esse sistema poderia ser aplicado à detecção de indicadores de monitoramento de ECG com alta precisão e confiabilidade, o que poderia ser amplamente adotado no diagnóstico clínico. Nível de evidência Il; Estudos terapêuticos- investigação dos resultados do tratamento.

Descritores: Eletrocardiografia; Testes de função cardíaca; Frequência cardíaca; Teste de esforço.

\section{RESUMEN}

Introducción: En este estudio se investigó un nuevo sistema de detección de electrocardiograma de esfuerzo (ECG) para diagnosticary analizar la función cardiopulmonary enfermedades relacionadas de manera integral y oportuna, y mejorar la precisión del diagnóstico. Además, se evaluó su confiabilidad y aplicabilidad clínica. Objetivo: Se construyó un nuevo tipo de sistema de detección de ECG de ejercicio agregando parámetros como la mecánica respiratoria, el dióxido de carbono y el monitoreo de la concentración de oxígeno sobre la base del sistema de detección de ECG tradicional. Métodos: El nuevo sistema construido en este estudio llevó a cabo la detección de la señal de ECG, el módulo de adquisición de ECG y la detección de la presión arterial y la mecánica 
respiratoria, y realizó una prueba de conformidad estándar. Resultados: la precisión de la frecuencia cardíaca detectada por el sistema de ECG de ejercicio fue mucho mayor que la de la detección manual del médico (P $<0,05)$. La precisión del nuevo sistema de detección de ECG de esfuerzo aumentó obviamente en contraste con el resultado de la detección manual $(P<0.05)$. Los resultados de la prueba de impedancia de entrada y ruido de entrada de índice técnico clave (24,5 $\mu V$ y 12,4 M 2$)$ del sistema de detección de ECG de esfuerzo cumplieron con el estándar $(<30 \mu \mathrm{V} y>2,5 \mathrm{M} \Omega$ ). Los resultados de la prueba de frecuencia de muestreo y rechazo en modo común $(103,5 \mathrm{~dB}$ y $515 \mathrm{~Hz})$ de los indicadores técnicos clave en el sistema de detección de ECG de esfuerzo estaban en línea con los estándares ( $\geq 89 \mathrm{~dB}$ y $\geq 500 \mathrm{~Hz}$ ). Conclusión: El sistema completo de detección de ECG de ejercicio se construyó mediante la combinación del módulo de adquisición de ECG, la detección de la presión arterial y el módulo de detección de la mecánica respiratoria. Además, este sistema podría aplicarse a la detección de indicadores de monitoreo de ECG con alta precisión y confiabilidad, que también podría adoptarse ampliamente en el diagnóstico clínico. Nivel de evidencia ll; Estudios terapéuticos-investigación de los resultados del tratamiento.

Descriptores: Electrocardiografía; Pruebas de función cardíaca; Frecuencia cardíaca; Teste de esforço; Prueba de esfuerzo.

\section{INTRODUCTION}

Exercise ECG refers to the ECG under a certain exercise load, which is often used for the diagnosis, differential diagnosis, and prognosis evaluation of coronary heart disease and other diseases. ${ }^{1,2}$ It can detect changes in the heart during exercise. Sometimes abnormal ECG can only occur during exercise or only be observed when there are symptoms. ${ }^{3,4}$ Through the analysis and determination of ECG related parameters, the subject's cardiac function status and myocardial ischemia can be judged., ${ }^{5,6}$ Although coronary angiography (CAG) is the "gold standard"for diagnosing coronary heart disease at present, it is technically difficult, invasive, and expensive, and can't be fully popularized. Exercise ECG is the form of exercise that causes the highest myocardial oxygen consumption. Therefore, it is a critical auxiliary method for the non-invasive detection and diagnosis of cardiovascular diseases.,78 Exercise ECG was originally mainly used for auxiliary diagnosis of coronary heart disease, determination of severity of coronary artery disease, prognosis, and curative effect. ${ }^{9,10}$

Therefore, the new type of exercise ECG detection system was constructed in this study, which was added with parameters such as respiratory mechanics, carbon dioxide and oxygen concentration monitoring on the basis of the traditional ECG detection system. Furthermore, the application values of this new exercise ECG detection system was analyzed in terms of the diagnosis and analysis of cardiopulmonary function and related diseases, and reflected the cardiopulmonary function of patients.

\section{METHODS}

\section{Cardiac conduction system}

The schematic diagram of the cardiac conduction system was shown in Figure 1. There was a certain potential difference between two different points on the human body surface. ${ }^{11,12}$ The potential difference changed with the electrical activity of the myocardium, and the potential difference showed a certain periodicity with the change of the myocardial activity. 13,14 By recording this periodic change as a changing curve was the clinical routine ECG.

\section{Detection of ECG signals}

The normal ECG signal consists of a certain sequence of $P$ waves (from the changes in the position of the atrial depolarization before atrial contraction), QRS waves (from the changes in the ventricular depolarization before ventricular contraction) and T waves (from potential changes during ventricular repolarization), PR segment, PR interval, ST segment, QT interval, $U$ wave composition, as shown in Figure 2.

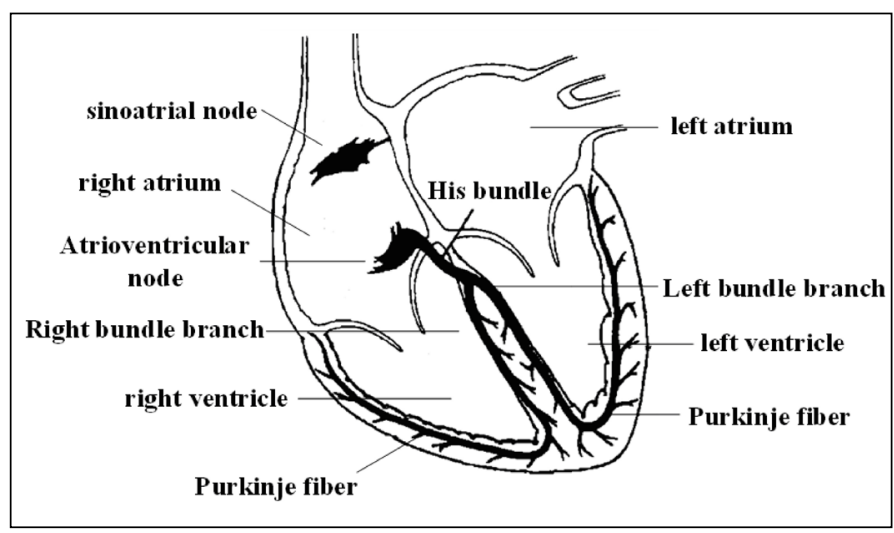

Figure 1. Cardiac conduction system.

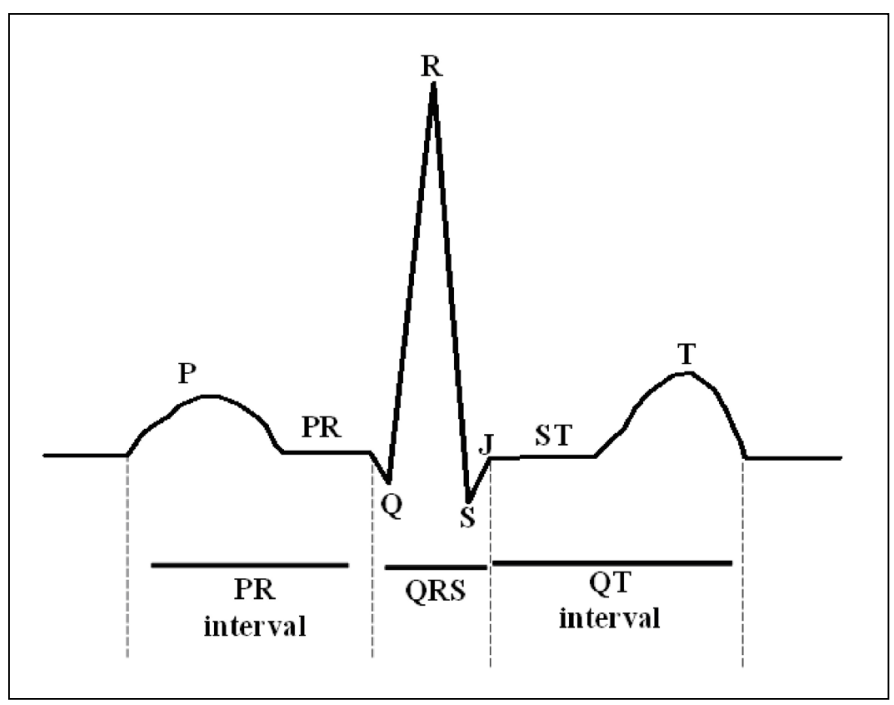

Figure 2. ECG signal waveform.

ECG acquisition includes two parts, namely analog acquisition and digital processing. The human body's ECG signal is collected through $\mathrm{AgCl}$ electrode and three-lead ECG acquisition line. After the signal is through pre-amplification circuit, band-pass filter circuit, and $50 \mathrm{~Hz}$ double T notch, the amplitude of the ECG signal is controlled within the A/D collection range of STM32 by the main amplifier circuit and the level lifting circuit. The STM32 sets the A/D sampling frequency through the timer, and the obtained digital signal was processed by means of average filtering. Figure 3 shows the design drawing of the power board for ECG data acquisition. 


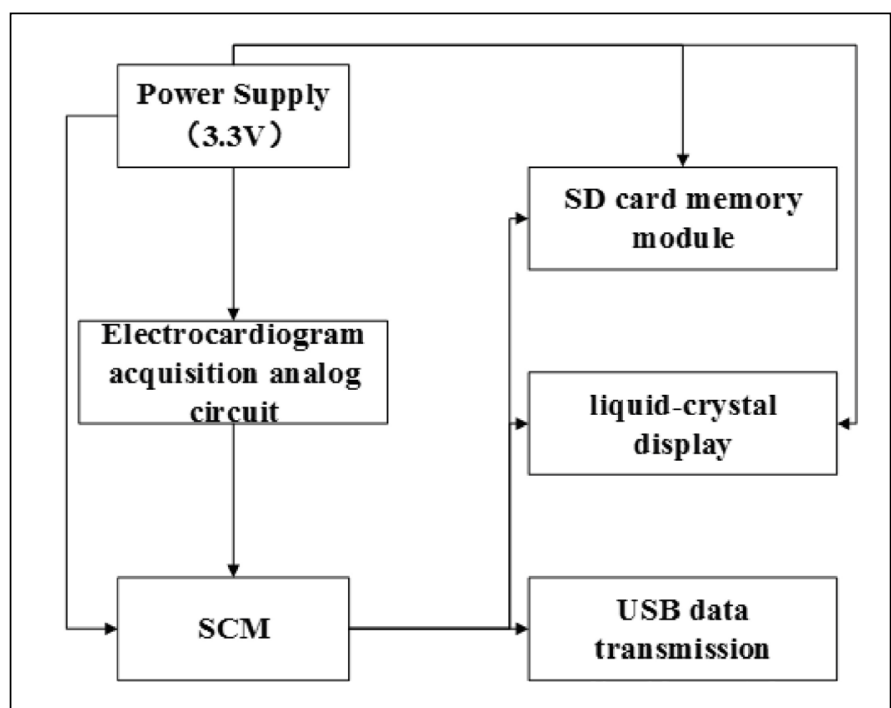

Figure 3. ECG data acquisition board.

\section{Monitoring of blood pressure and respiratory mechanics}

Oscillographic blood pressure monitoring was to determine blood pressure by establishing the relationship between systolic pressure (Ps), diastolic pressure (Pd), average pressure ( $\mathrm{Pm})$, and cuff pressure wave. The pressure sensor could sense the initial and maximum pulsation of the brachial artery, and the pressure signal was converted into an electrical signal through amplification and filtering. The static pressure DC component and pulsating AC component were extracted and given with the corresponding acquisition, so as to obtain the required measured value. Oscillographic method could eliminate the influence of operator's subjective factors and have a strong ability to resist environmental interference. In addition, pulse wave had a stable correlation with blood pressure, so the principle of Oscillographic method could be used to measure blood pressure.

Breathing exercises would cause changes in intrathoracic pressure, changes in intrathoracic pressure to result in changes in intrapulmonary pressure, and changes in intrapulmonary pressure to cause alveolar ventilation. By monitoring the internal pressure and flow rate of the respiratory airway, respiratory mechanics parameters such as expiratory tidal volume, intrapleural pressure, alveolar pressure, transairway pressure, and respiratory function could be derived. Monitoring carbon dioxide concentration and partial pressure could obtain changes in pulmonary ventilation and pulmonary blood flow, and carbon dioxide concentration monitoring was shown as follows.

$$
A=A_{0} e^{-\alpha X N}
$$

In the equation (1), A stood for the intensity of the emitted light, $A_{0}$ represented the intensity of the incident light, a meant the absorption coefficient, $N$ is the gas path concentration of carbon dioxide, and $X$ indicated the length of the measurement gas chamber.

\section{RESULTS}

\section{Heart rate monitoring of exercise ECG detection system}

In order to test and verify the practicability and accuracy of the exercise ECG detection system, the volunteers were selected randomly in this study. Besides, they were examined through the exercise ECG detection system for heart rate, ECG report, and ECG report / heart rate testing. Moreover, the test results were compared with the doctor's manual detection results, as shown in Figure 4. It revealed that the accuracy of the heart rate detected by the exercise ECG system was markeldy higher than that of the doctor's manual detection $(P<0.05)$.

\section{ECG report monitoring results of exercise ECG detection system}

Figure 5 indicated the comparison on the ECG reports between the exercise ECG and the manual detection by doctors. It was found that the accuracy of the detection results of the new exercise ECG detection system rose hugely in contrast to that of the manual detection results $(P<0.05)$. (Figure 6 )

\section{Exercise ECG module standard conformance test}

The input noise and input impedance test results of the key technical indicators of the system and the standard were compared, and the

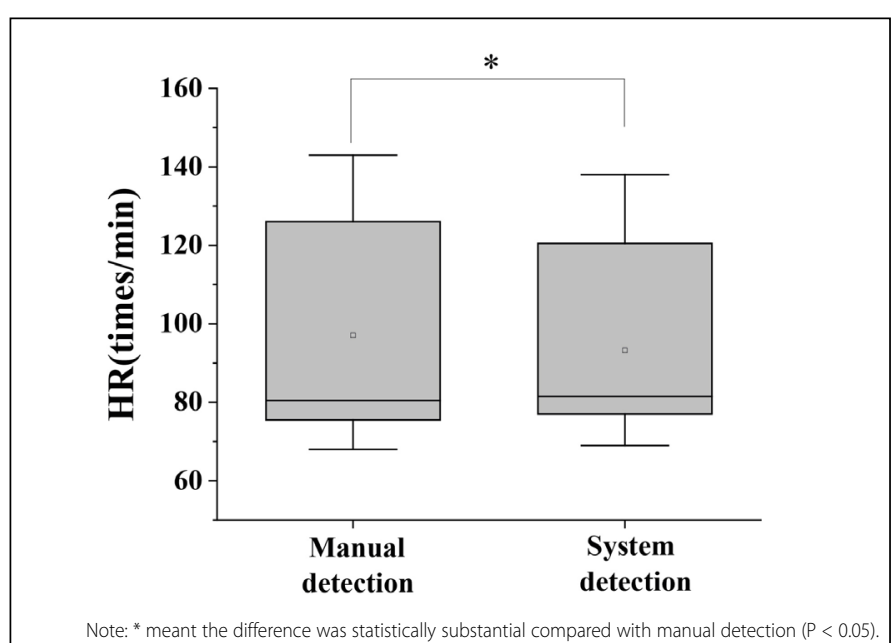

Figure 4. Comparison on the test results of heart rate.

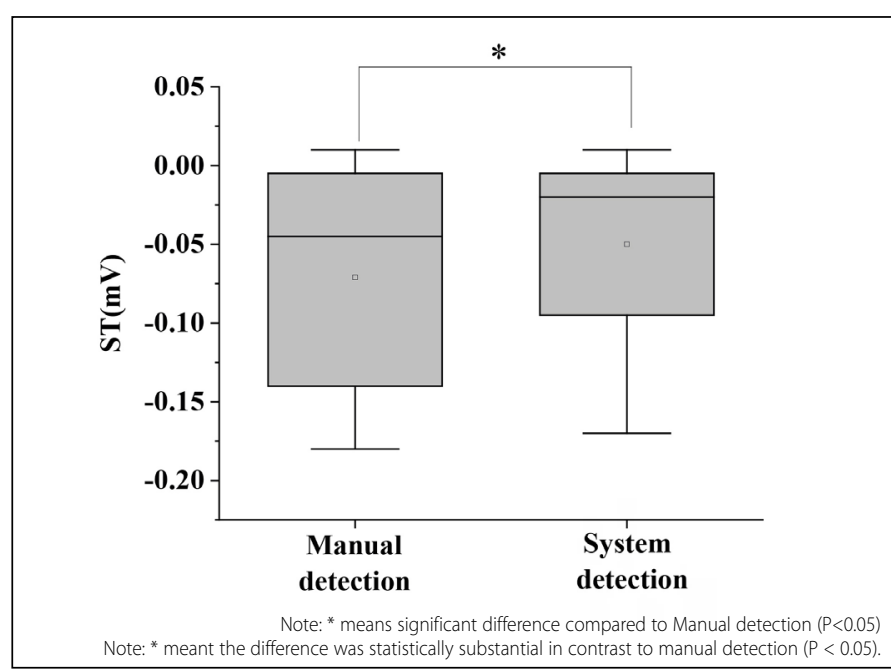

Figure 5. Comparison on ECG report results.

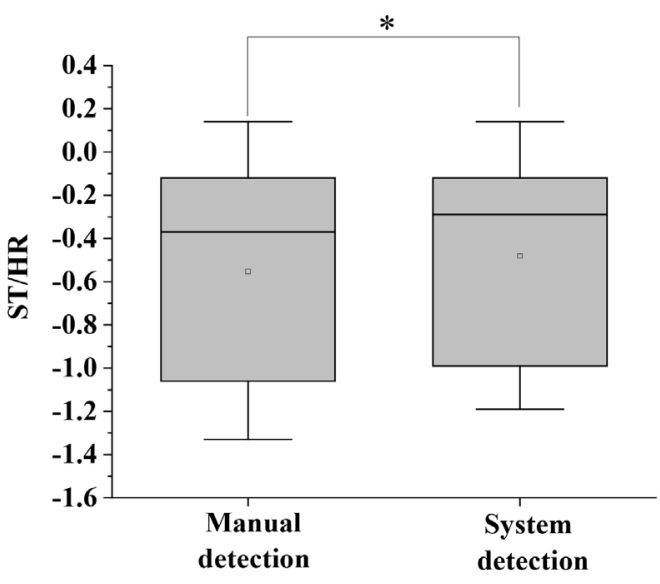

Note: * indicated the difference was statistically marked in contrast to manual detection $(P<0.05)$.

Figure 6. Comparison on ECG report / heart rate test results. 
results were shown in Figure 7. It was found that the input noise standard requirement of the exercise ECG acquisition module was less than $30 \mu \mathrm{V}$, the input impedance standard requirement was greater than $2.5 \mathrm{M} \Omega$, while the test results were $24.5 \mu \mathrm{V}$ and $12.4 \mathrm{M} \Omega$, respectively. The input noise and input impedance test results of the key technical indicators of the exercise ECG detection system met the standards.

\section{Acquisition module standard conformance test}

Figure 8 revealed the comparison on the common mode rejection and sampling rate test results of the key technical indicators of the system and the standard. It showed that the common mode rejection standard requirement of the exercise ECG acquisition module was $\geq 89 \mathrm{~dB}$, the

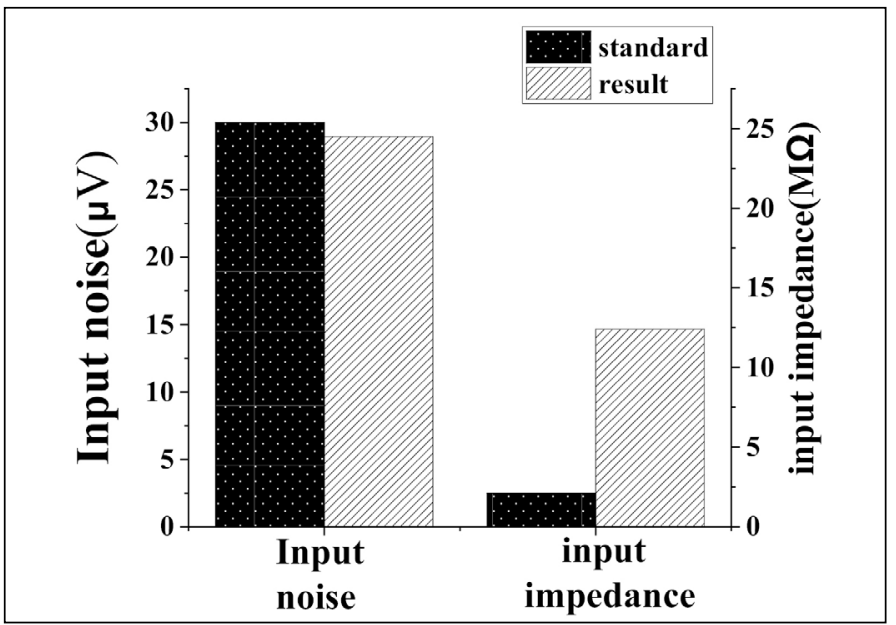

Figure 7. Input noise and input impedance test results.

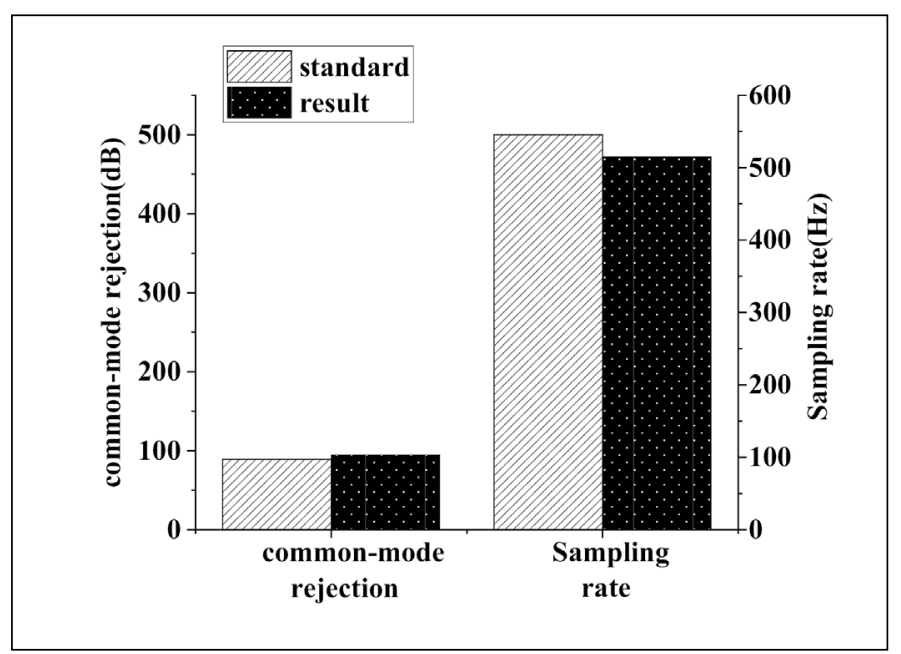

Figure 8. Common mode rejection and sampling rate test results. sampling rate standard requirement was $\geq 500 \mathrm{~Hz}$. However, the test results were $103.5 \mathrm{~dB}$ and $515 \mathrm{~Hz}$, respectively. Therefore, the common mode rejection and sampling rate test results of key technical indicators of exercise ECG detection system were in line with the standard.

\section{DISCUSSION}

During exercise, the probability of unexpected events such as sudden death increases sharply. ${ }^{15-16}$ Cardiovascular diseases are a serious threat to human life and health and cause a huge economic burden to society and families. ${ }^{17}$ Due to untimely monitoring, the disease can't be effectively treated. Therefore, real-time monitoring of the ECG activity is highly practical and necessary. The monitoring center would feed back the diagnosis results and corresponding treatment measures to the ECG monitoring terminal patients through the network in the form of text messages, and inform the ward and the guardian, to achieve real-time monitoring of the heart of the ward.

In this study, a new type of exercise ECG detection system was constructed by adding parameters such as respiratory mechanics, and carbon dioxide and oxygen concentration monitoring on the basis of the traditional ECG monitoring system. What's more, its application was analyzed in the diagnosis and analysis of cardiopulmonary function and related diseases, as well as the response of patients' heart and lung function status. As a result, there was no statistically marked difference between the heart rate detected by exercise ECG and manual detection by doctors $(P>0.05)$. The key technical indicators of the exercise ECG module of the exercise ECG detection system were input noise, input impedance, common mode rejection, and sampling rate test results, which all met the standards. This system could be applied to the detection of ECG monitoring indicators, which was more accurate and reliable. Furthermore, it could be widely adopted in clinical diagnosis.

\section{CONCLUSION}

By adding parameters such as respiratory mechanics, carbon dioxide and oxygen concentration monitoring based on the traditional ECG monitoring system, a new type of exercise ECG detection system was established in this study. Besides, there was an analysis on its application in the diagnosis and analysis of cardiopulmonary function and related diseases, as well as the reflection of heart and lung functional status. The results found that a complete exercise ECG detection system was constructed through the combination of ECG acquisition module, blood pressure detection and respiratory mechanics detection module. This system could be applied to the detection of ECG monitoring indicators with high accuracy and reliability. Moreover, it could be also applied in the clinical diagnosis.

All authors declare no potential conflict of interest related to this article

AUTHORS' CONTRIBUTIONS: Each author made a significant personal contribution to the manuscript. Meng Zhang established a new type of exercise ECG detection system. Yifei Zhai did an analysis on its application in the diagnosis and analysis of cardiopulmonary function and related diseases, as well as the reflection of heart and lung functional status.

\section{REFERENCES}

1. Nguyen LTN, Eager D, Nguyen $H$. The relationship between compression garments and electrocardiogram signals during exercise and recovery phase. Biomed Eng Online. 2019;18(1):27.

2. Shabaan M, Arshid K, Yaqub M, Jinchao F, Zia MS, Bojja GR, et al. Survey: smartphone-based assessment of cardiovascular diseases using ECG and PPG analysis. BMC Med Inform Decis Mak. 2020;20(1):177.

3. LiY, Yu X, Hu Y, Cao Z. [Exercise-sensitive indices screening from electrocardiogram based on rest-workload alternating pattern]. Sheng Wu Yi Xue Gong Cheng Xue Za Zhi. 2015;32(2):249-55. Chinese.

4. Molina GE, Fontana KE, Porto LG, Junqueira LF Jr. Post-exercise heart-rate recovery correlates to resting heart-rate variability in healthy men. Clin Auton Res. 2016;26(6):415-21.

5. Mulder MB, Eidelson SA, Buzzelli MD, Gross KR, Batchinsky Al, Convertino VA, et al. Exercise-induced changes in compensatory reserve and heart rate complexity. Aerosp Med Hum Perform. 2019;90(12):1009-15.
6. Hernando D, Garatachea N, Almeida R, Casajús JA, Bailón R. Validation of heart rate monitor polar RS800 for Heart Rate variability analysis during exercise. J Strength Cond Res. 2018;32(3):716-25.

7. Gilgen-Ammann R, Schweizer T, Wyss T. RR interval signal quality of a heart rate monitor and an ECG Holter at rest and during exercise. Eur J Appl Physiol. 2019;119(7):1525-32.

8. Gambassi BB, Almeida FJF, Almeida AEAF, Ribeiro DAF, Gomes RSA, Chaves LFC, et al. Acute response to aerobic exercise on autonomic cardiac control of patients in phase III of a cardiovascular rehabilitation program following coronary artery bypass grafting. Braz J Cardiovasc Surg. 2019;34(3):305-10.

9. Thomson EA, Nuss K, Comstock A, Reinwald S, Blake S, Pimentel RE, et al. Heart rate measures from the Apple Watch, Fitbit Charge HR 2, and electrocardiogram across different exercise intensities. J Sports Sci. 2019;37(12):1411-9.

10.Hamm W, VON Stülpnagel L, Rizas KD, Vdovin N, Klemm M, Bauer A, et al. Dynamic 
changes of cardiac repolarization instability during exercise testing. Med Sci Sports Exerc. 2019;51(7):1517-22.

11. Teferra MN, Ramos JS, Kourbelis C, Newman P, Fleury A, Hobbs D, et al. Electronic textile-based electrocardiogram monitoring in cardiac patients: a scoping review. JBI Database System Rev Implement Rep. 2019;17(10):1958-98.

12. Hung CH, Clemente FM, Bezerra P, Chiu YW, Chien CH, Crowley-McHattan Z, et al. Post-exercise recovery of ultra-short-term heart rate variability after yo-yo intermittent recovery test and repeated sprint ability test. Int J Environ Res Public Health. 2020;17(11):4070.

13. Brouwers RW, Kraal JJ, Traa SC, Spee RF, Oostveen LM, Kemps HM. Effects of cardiac telerehabilitation in patients with coronary artery disease using a personalised patient-centred web application: protocol for the SmartCare-CAD randomised controlled trial. BMC Cardiovasc Disord. 2017;17(1):46
14. Hsu CC, Lin BS, He KY, Lin BS. Design of a wearable 12-lead noncontact electrocardiogram monitoring system. Sensors (Basel). 2019;19(7):1509.

15. Hupin D, Edouard P, Oriol M, Laukkanen J, Abraham P, Doutreleau S, et al. Exercise electrocardiogram in middle-aged and older leisure time sportsmen: 100 exercise tests would be enough to identify one silent myocardial ischemia at risk for cardiac event. Int J Cardiol. 2018;257:16-23.

16. Choi JO, Chang SA, Park SJ, Lee SC, Park SW. Improved detection of ischemic heart disease by combining high-frequency electrocardiogram analysis with exercise stress echocardiography. Korean Circ J. 2013;43(10):674-80.

17. Takagi Y, Hozumi T, Takemoto Y, Negishi K, Hong Z, Abo K, et al. Detection of prolonged regional myocardial systolic dysfunction after exercise-induced myocardial ischemia by strain echocardiography with high frame rate tissue Doppler echocardiography. J Echocardiogr. 2011;9(3):90-6. 